\title{
Both landscape heterogeneity and configuration determine Woodlarks (Lullula arborea) breeding territories
}

\author{
Marlies Resch $^{1}$, Marcela Suarez-Rubio ${ }^{\text {Corresp. } 1}$ \\ ${ }^{1}$ Institute of Zoology, Department of Integrative Biology and Biodiversity Research, University of Natural Resources and Life Sciences, Vienna, Austria \\ Corresponding Author: Marcela Suarez-Rubio \\ Email address: marcela.suarezrubio@boku.ac.at
}

Farmland birds have declined in the last decades mostly due to agriculture intensification. The Woodlark Lullula arborea, a farmland species of conservation concern and protected by the European Bird Directive, occurs in a variety of habitats across its geographic range. Although habitat heterogeneity has been recognized as a key feature, the preference or avoidance of particular habitat attributes might differ across its range because different localities may have distinct conditions. Such variation would challenge conservation efforts at the local level. Our aim was to assess habitat associations of Woodlarks and determine whether the habitat attributes identified as important in other locations across its range could be generalised and applied to Austrian populations. In addition, habitat associations can be influenced by land-use change. We examined changes in land use from 2007 to 2016 in 15 municipalities surrounding areas occupied by Woodlarks. We quantified the composition and configuration of the local landscape surrounding 18 singing males' territories and 16 non-territory sites. We found that the probability of Woodlarks territories increased with landscape heterogeneity between $50-70 \%$, increased with dispersed bare soil patches, decreased with overall patch density and were away from dirt roads. Contrary to our expectation, there was no indication of land-use change. In contrast to previous studies, vegetation height, the presence and proximity to woodland were not identified as important habitat characteristics. Thus, some conservation recommendations can be derived from other localities, for example, maintaining or enhancing landscape heterogeneity. However, others should be adapted to local conditions. In Austria, conservation efforts should focus on including dispersed patches of bare soil and limiting the development of dirt roads nearby Woodlark territories, in addition to promoting a heterogeneous landscape. 
1 Both landscape heterogeneity and configuration determine Woodlarks (Lullula arborea)

2 breeding territories

3

4 Marlies Resch, Marcela Suarez-Rubio

5 Institute of Zoology, University of Natural Resources and Life Sciences, Vienna, Austria

7 Corresponding author

8 Marcela Suarez-Rubio

9 Gregor-Mendel-Strasse 33, 1180 Vienna, Austria

10 Email address: marcela.suarezrubio@boku.ac.at

11 ORCID: 0000-0002-0596-2626

12 


\section{Abstract}

14 Farmland birds have declined in the last decades mostly due to agriculture intensification. The

15 Woodlark Lullula arborea, a farmland species of conservation concern and protected by the

16 European Bird Directive, occurs in a variety of habitats across its geographic range. Although

17 habitat heterogeneity has been recognized as a key feature, the preference or avoidance of

18 particular habitat attributes might differ across its range because different localities may have

19 distinct conditions. Such variation would challenge conservation efforts at the local level. Our

20 aim was to assess habitat associations of Woodlarks and determine whether the habitat attributes

21 identified as important in other locations across its range could be generalised and applied to

22 Austrian populations. In addition, habitat associations can be influenced by land-use change. We

23 examined changes in land use from 2007 to 2016 in 15 municipalities surrounding areas

24 occupied by Woodlarks. We quantified the composition and configuration of the local landscape

25 surrounding 18 singing males' territories and 16 non-territory sites. We found that the probability

26 of Woodlarks territories increased with landscape heterogeneity between $50-70 \%$, increased with

27 dispersed bare soil patches, decreased with overall patch density and were away from dirt roads.

28 Contrary to our expectation, there was no indication of land-use change. In contrast to previous

29 studies, vegetation height, the presence and proximity to woodland were not identified as

30 important habitat characteristics. Thus, some conservation recommendations can be derived from

31 other localities, for example, maintaining or enhancing landscape heterogeneity. However, others

32 should be adapted to local conditions. In Austria, conservation efforts should focus on including

33 dispersed patches of bare soil and limiting the development of dirt roads near Woodlark

34 territories, in addition to promoting a heterogeneous landscape. 


\section{Introduction}

36 Farmland birds are declining at unprecedented rates in Europe, although the rate of decline may

37 have decreased since the mid-1990s (e.g., Donald et al. 2006; Gregory et al. 2019). An important

38 driver for this decline is agricultural intensification (Chamberlain et al. 2000; Jerrentrup et al.

39 2017), which includes changing the crop management including type and relative abundance of

40 different crops, shifting the timing of some agricultural management activities and increasing the

41 use of artificial fertilizers and herbicides (Chamberlain et al. 2000; Donald et al. 2001; Stanton et

42 al. 2018). In addition, habitat homogenisation through the loss or reduction of important

43 landscape elements like hedgerows has also contributed to the decline of farmland birds (Benton et al. 2003; Stanton et al. 2018). Intense farming can modify the preferred farmland bird habitats which affect the required conditions for both breeding habitat and food resources (Gil-Tena et al. 2015). For farmland birds, therefore, detailed knowledge of the habitat requirements of each species is key for augmenting their populations (Whittingham et al. 2005).

One of the farmland birds susceptible to habitat modification caused by agricultural intensification is the Woodlark (Lullula arborea). Woodlarks are insectivorous and groundnesting birds that occur mainly in Europe, northern Africa and western Asia. They are listed in the Annex I of the European Bird Directive (79/409/EEC of 2 April 1979). Although there has been a recent trend toward a moderate increase (EBCC 2021), the population size has fluctuated greatly in Europe recently, mainly due to habitat changes on their breeding grounds (Takacs et al. 2020). In Austria, Woodlarks are classified as vulnerable in the Austrian Red List (Dvorak et al. 2017), and few populations occur in Upper Austria (Uhl and Wichmann 2013), Lower Austria (Straka 2008) and Lake Neusiedl (Dvorak et al. 2009). In Upper Austria, the Woodlark 
582017 (Uhl and Wichmann 2018). Thus, identifying local habitat associations and understanding

59 the role of local land-use change in altering their habitats is of great importance.

60 It is common that bird-habitat associations measured in one area are taken as representative

61 for the species, like a species-specific trait (Wesołowski and Fuller 2012). However, habitat

62 associations are not temporally/spatially uniform for many bird species (Fuller 2002; Fuller and

63 Rothery 2013). These associations can change due to, for example, changes in the type of habitat

64 available, behavioral flexibility, or variations in population density (Havlíček et al. 2021;

65 Newson et al. 2009; Wesołowski and Fuller 2012). In Britain, for example, Woodlarks habitat

66 associations have changed over time (Wright et al. 2007). They have been traditionally

67 associated with heathland (Holloway 1996). However, since the 1970s, they are associated with

68 clear-fell forestry habitats (Sitters et al. 1996; Wotton and Gillings 2000). This shift has occurred

69 due to changes in land use and habitat availability (Holloway 1996; Sharrock 1976), which

70 highlights the importance of evaluating land-use change as a potential factor affecting habitat

71 associations.

72 In addition, bird-habitat associations can vary spatially across a species' geographic range.

73 Woodlarks, for example, are associated with heathlands (Mallord et al. 2007) and forest clear

74 cuts in Britain (Wright et al. 2007), Christmas-tree plantations in Germany (Fartmann et al.

75 2018), vineyards in Switzerland (Arlettaz et al. 2012; Bosco et al. 2019; Buehler et al. 2017), and

76 crop-steppes in Italy (Campedelli et al. 2015). Therefore, a species might occupy different

77 habitats across its range to reflect different limiting factors or abiotic conditions (e.g., Boves et

78 al. 2013; Koleček et al. 2015; Piotr et al. 2011; Wesołowski and Fuller 2012; Whittingham et al.

79 2007). 
The preference or avoidance of habitat attributes has been evaluated previously in different

81 Woodlark habitats and at different scales in an attempt to understand population trends and

82 develop conservation strategies. It has been found that Woodlarks are associated with tall and

83 dense ground vegetation (Buehler et al. 2017; Mallord et al. 2007) at the microhabitat scale $(\sim 5$

$84 \mathrm{~m}$ around the nest) in vineyards and heathlands. Further, a mosaic of grass, herbs and bare soil is

85 preferred in orchards and vineyards (Arlettaz et al. 2012; Schaub et al. 2010). Besides bare soil,

86 open grassland and sparse cover of bushes and trees are favoured at the mesohabitat scale $(\sim 50$

$87 \mathrm{~m}$ ) in grasslands/croplands, heathlands and forestry areas (Sirami et al. 2011; Sitters et al. 1996).

88 An interplay between habitat amount (i.e., area of available habitat) and habitat fragmentation

89 emerges in vineyards at the macrohabitat scale $(\sim 100 \mathrm{~m})$ (Bosco et al. 2021). If habitat amount is

90 below 20\% Woodlarks avoid fragmented areas, but if habitat amount exceeds $20 \%$ then there is a

91 preference for fragmented areas. In addition, the degree of connectivity is also relevant when the

92 spatial arrangement of habitat elements is evaluated in crop-steppes at the macrohabitat scale

93 (Campedelli et al. 2015).

94 Although habitat heterogeneity at multiple scales has been identified as a key factor for

95 Woodlarks (Sirami et al. 2011) and farmland birds in general (Benton et al. 2003), it is unclear

96 whether other previously identified habitat associations can be generalized to other habitats. If

97 habitat preferences recognized in one habitat do not apply in other habitats, then it may result in

98 developing inappropriate conservation strategies. Indeed, effective conservation measures

99 depend on detailed knowledge about the variation in response across the species' range. Hence,

100 management strategies must also vary locally (Wesołowski and Fuller 2012; Whittingham et al.

101 2007). 
103 grassland-forest mosaic in Upper Austria and determine whether the habitat characteristics

104 identified as important in other habitats across its range (e.g., vineyards) were also important or

105 have similar ranking of importance. We evaluated both habitat amount and the spatial

106 arrangement of habitat elements and human features (i.e., configuration) at the macrohabitat

107 scale (i.e., local landscape sensu Fahrig 2013) to better understand whether previous

108 conservation recommendations can be applied in other habitats or should be verified locally for

109 effective conservation measures. In addition, we examined changes in land use from 2007 to

1102016 because ongoing agriculture intensification, in particular changes in type and area occupied

111 by different crops has been documented in Upper Austria (van der Sluis et al. 2016).

112 Additionally, change in areas of major land-cover types (e.g., grassland) could result in simple

113 reduction of the amount of habitat available for Woodlarks (Reif and Hanzelka 2016).

114 Altogether, this knowledge can be used to provide adequate support to this vulnerable species.

\section{Materials \& Methods}

\section{Study area}

117 The study was conducted in the Mühlviertel region located in the north-eastern part of Upper

118 Austria, Austria (Central Europe) (Fig. 1). It covers an area of 3,090 km² and has around 270000

119 inhabitants. Within the Mühlviertel region, we focused on the Nature Park (Rechberg $48^{\circ} 19^{\prime}$ N,

$\left.12014^{\circ} 42^{\prime} \mathrm{E}\right)$ in the east and Neumarkt (Neumarkt im Mühlkreis $48^{\circ} 25^{\prime} \mathrm{N}, 14^{\circ} 29^{\prime} \mathrm{E}$ ) in the north.

121 These are areas located approximately $20 \mathrm{~km}$ apart and include the main population of

122 Woodlarks in Upper Austria (Uhl 2009; Uhl and Wichmann 2013). We received oral consent

123 from Barbara Derntl from the Nature Park Mühlviertel to access their premises. Some sampling

124 was conducted on private land with the owners' consent. 
The region has a continental climate, and the mean annual temperature is between $5-9{ }^{\circ} \mathrm{C}$.

126 The area is characterized by hills and a mixture of forest, grassland and cropland. In some parts,

127 the region is rich in habitat elements, like groves (clusters of trees), isolated trees and hedgerows,

128 and in other parts these elements are scarce. Around a quarter of the agricultural area is

129 cultivated organically, and the average farm size is around 30 ha (BMLFUW 2017).

\section{Territory mapping}

131 Based on previous sightings and territories (Uhl 2009; Uhl and Wichmann 2013), we mapped

132 territories of 18 singing males during the breeding season of 2017 to determine the distribution

133 of territorial Woodlarks throughout the study area (Fig. 1). The territory mapping was performed

134 following Südbeck et al. (2005). The area was surveyed six times systematically from 13 March

135 to 19 May between sunrise and 10:00 h during days without rain or strong winds (Beaufort wind

136 force $<4$ ). During each survey, we recorded Woodlark's location using a global positioning

137 system, behaviour (singing or foraging) and position (e.g., on the ground, on top of tree).

138 Observations of individuals singing in flight were excluded as they could not be associated with

139 any habitat use. The territory centre either corresponded to the centre of the Woodlark territory in

140 most cases or to the nest, in the few instances where we were able to find the nest. Using the

141 function "create random points" in ArcGIS v. 10.5.1 (ESRI 2017), we randomly selected 16

142 locations within the study area where no Woodlarks were recorded and corresponded to pseudo-

143 absence (hereafter referred as "absence"). Random points that fell on water bodies or on already

144 occupied territories were excluded. The minimum distance between Woodlark territories and

145 absence areas was $266 \mathrm{~m}(1150 \pm 718 \mathrm{~m})$ and there was little or no overlap between territories. 


\section{Habitat characteristics}

147 We established a $150 \mathrm{~m}$ radius around the centre of the territories and absence areas, which

148 equals approximately 7 ha. We selected this size to capture the size range of Woodlarks

149 territories (Harrison and Forster 1959). It also corresponds to the average territory size of

150 Woodlarks in this region (Uhl 2009). For characterizing the macrohabitat within the study plots

151 of 7 ha between April and May 2017, we divided habitat elements into two categories: land

152 use/land cover and linear elements. We assigned 11 land use/land cover classes: bare soil,

153 grassland, cropland with short $(<20 \mathrm{~cm})$ and tall $(20-150 \mathrm{~cm})$ vegetation, rough pastures (i.e.,

154 non-intensive grazing pastures), forest, groves, residential areas, dirt roads, asphalt roads, and

155 water bodies. We estimated the area covered for each of the land use/land cover classes,

156 measured the height of grassland, cropland, rough pastures, vegetation between the track lanes of

157 dirt roads, estimated the height of forest, groves, and measured the diameter at breast height

158 (DBH) for forest and groves. Given that vegetation patches varied in size, we allocated a number

159 of measuring points in each vegetation patch based on its size (e.g., from 2 measuring points in

160 patches of $<0.7$ ha up to 20 measuring points for patches of $>6.4$ ha). The minimum distance

161 between measuring points was $10 \mathrm{~m}$ and the placement of the measuring points was random.

162 Land use/land cover patches smaller than $15 \mathrm{~m}^{2}$ were not characterized and were included as part

163 of adjacent larger patches. In addition, we measured the length of linear elements such as dirt

164 roads, asphalt roads, electricity lines, and hedgerows. We estimated the distance from the centre

165 of the territory to linear elements and to forest and groves.

166 We used ArcGIS v. 10.5.1 (ESRI 2017) to digitize the collected field data. To determine

167 the arrangement of the different of land use/land cover classes in the sampling plots (i.e., spatial

168 configuration) we calculated landscape metrics using FRAGSTATS v 4.2 (McGarigal et al. 
169 2012). For the whole sampling plot, we calculated overall patch density (number of patches per

$170100 \mathrm{ha})$ as it is a useful metric of landscape configuration in which it indicates whether patches

171 were small and numerous in the landscape or if they were mainly large and few patches.

172 Landscape shape index measures the overall geometric complexity and can be interpreted as a

173 measure of landscape dispersion - the greater the value, the more dispersed are the patch types

174 (McGarigal et al. 2012). Mean proximity index calculates the degree of patch isolation by

175 considering both the size and the proximity to all patches. The index distinguishes sparse

176 distributions of small habitat patches from configurations where the habitat forms a complex

177 cluster of larger patches. Contagion index measures both patch type interspersion (i.e., the

178 intermixing of different patch types) as well as patch dispersion (i.e., the spatial distribution of a

179 patch type), and Simpson diversity index calculates the heterogeneity of the landscape

180 (McGarigal et al. 2012). A higher value of Simpson's diversity index means greater

181 compositional heterogeneity. We also calculated patch density and the landscape shape index for

182 each of the land use/land cover classes (Table S1).

\section{Land-use change}

184 We used agricultural land-use data of the area of Mühlviertel from the years 2007, 2012 and

1852016 provided by the Austrian Federal Ministry of Agriculture, Forestry, Environment and

186 Water Management to identify land-use changes. The focus of this analysis was on the 15

187 municipalities where Woodlarks were recorded from 2007 until 2016 (Uhl 2009; Uhl and

188 Wichmann 2013, 2018). For the 15 municipalities in this region, four land-use types were

189 analysed: Grassland included wildflower margins, permanent pasture, managed meadows (cut

190 one to three times per year) and seeded pastures. Cropland included different types of legumes,

191 field forage, summer grain, winter grain, potato, corn and other field crops. Woody vegetation 
192 referred to Christmas trees, energy forests (i.e., fast-growing trees with the aim of producing

193 wood chips), tree nurseries, and different types of fruit trees. Protected comprised protected

194 arable land ('Landschaftselement Acker'), protected grassland ('Landschaftselement Grünland'),

195 protected natural monuments and protected areas that have good agricultural and environmental

196 conditions (GAECs).

\section{Data analysis}

198 We performed a conditional Random forest algorithm (Breiman 2001; Hothorn et al. 2006) to 199 rank the 56 explanatory variables (Table S1) according to their importance. The magnitude of 200 importance of the predictors was compared using the Conditional Variable Importance values

201 from the random forest approach. Conditional Variable Importance calculates the mean decrease

202 of prediction accuracy of the response variable devoted to an explanatory variable after

203 permuting it over all data and avoids overestimating the importance of correlated predictor

204 variables (Strobl et al. 2008). We used the cforest function from the R package "partykit"

205 (Hothorn and Zeileis 2015) with 5000 bootstrap samples and mtry=p/3 variables at each split.

206 We checked for multicollinearity of the most important variables identified by the

207 conditional Random forest algorithm using variance inflation factor (VIF) with the R-package

208 "usdm" (Naimi 2015). Those variables with VIF $>2$ were excluded from further analysis. To

209 determine which habitat characteristics were the most important for the Woodlarks in the

210 Mühlviertel, a Generalized Estimating Equation model was performed with the response variable

211 absence (0) and presence (1) of Woodlarks in the study plots and the remaining five explanatory

212 variables. These variables were landscape heterogeneity, patch density, landscape shape index of

213 bare soil, percentage of dirt roads, and distance from dirt roads. We included the region as a

214 random factor and the correlation structure "AR-1" to account for the spatial correlation of the 
215 data (package "geepack"; Højsgaard et al. 2006). Model selection was completed via model

216 averaging (package "MuMIn"; Barton 2020) to show the influence of all variables where QIC

217 (Quasi Information Criteria) change was smaller than two (Zuur et al. 2009).

218 We performed a compositional data analysis to test whether land-use types (i.e., grassland,

219 cropland, woody vegetation and protected) changed in the 15 municipalities where Woodlarks

220 occurred from 2007 to 2016 . The response variable was the land-use type and represents

221 compositional data because scores for each class are proportions of the total area covered and

222 therefore are interdependent (Aitchison 1982). The explanatory variable was year (2007, 2012

223 and 2016). We performed an analysis of variance (ANOVA) adjusted to compositions (van den

224 Boogaart and Tolosana-Delgado 2013) as this technique accounts for the dependence of the

225 compositions and inspected the residuals and checked for symmetry and normality within the

226 package "compositions" (van den Boogaart et al. 2021). All the statistical analyses were done

227 with R v. 4.0 .3 (R Core Team 2020).

\section{Results}

229 The most important variables for the occurrence of Woodlark territories were landscape

230 heterogeneity, length of dirt road, proportion of dirt roads, overall patch density, landscape shape

231 index of bare soil, patch density of grassland, proportion of bare soil, distance from dirt roads,

232 and contagion index (Fig. 2). The variance inflation factor (VIF) of the most important variables

233 showed that length of dirt road, patch density of grassland, proportion of bare soil, and contagion

234 index had a VIF $>2$, and they were therefore excluded from further analysis.

The Generalized Estimated Equation model showed that the strongest predictors on the

236 occurrence of Woodlark territories were landscape heterogeneity, distance from dirt roads, 
237 landscape shape index of bare soil and overall patch density (Table 1). All Woodlark territories

238 occurred in areas with a mixture of grasslands (average $25 \%$ ), croplands with short $(<20 \mathrm{~cm}$ )

239 and tall $(20-150 \mathrm{~cm})$ vegetation $(12 \%$ and $21 \%$, respectively), forest $(23 \%)$ and bare soil $(10 \%)$.

240 The probability of the occurrence of a Woodlarks territory increased sharply with landscape

241 heterogeneity between 50 and $70 \%$, increased with the degree of dispersion of bare soil patches,

242 increased with distance from dirt roads, and decreased with overall patch density (Fig. 3).

243 When evaluating land-use types in the 15 municipalities where Woodlarks occurred from

2442007 to 2016, cropland covered most of the area (66.6\%), followed by grassland (28.9\%).

245 Woody vegetation and protected areas together covered 4.5\%. The proportions of these land-use

246 types did not differ among years $\left(F_{2,21}=0.8108, \mathrm{df}=2, \mathrm{p}=0.458\right.$; Fig. 4). Thus, there was no

247 indication of land-use change between 2007, 2012 and 2016.

\section{Discussion}

249 Our results show that Woodlarks were associated with landscape heterogeneity (quantified as

250 Simpson diversity index), overall patch density, landscape shape index of bare soil and distance

251 from dirt roads. Landscape heterogeneity has been previously identified as a key characteristic in

252 other habitats across the Woodlark's range such as in Christmas-tree plantations (Fartmann et al.

253 2018), Mediterranean landscapes (Sirami et al. 2011), low-intensity agricultural systems

254 (Brambilla et al. 2012) and vegetated vineyards (Bosco et al. 2019). Although it was the most

255 important predictor of Woodlark occurrence, the components of heterogeneity varied in the

256 different habitats. For example, in Christmas-tree plantations, Woodlarks favour the high habitat

257 structure of trees of different age growing along large areas of bare soil and gravel between the

258 tree lines (Fartmann et al. 2018). In Mediterranean landscapes, open shrubland intermixed with

259 tall grass/herbs and bare soil were preferred. In vineyards, Woodlarks were associated with high 
260 ground vegetation cover, plant species richness and wider inter-rows (Bosco et al. 2019). In our

261 study, Woodlark territories were in areas with a mixture of grasslands, croplands with short and

262 tall vegetation, forest and bare soil. Therefore, the combination of different habitat elements

263 enhances the access to a range of resources necessary to meet vital needs as postulated in the

264 complementation hypothesis (Dunning et al. 1992). It has been shown that heterogenous

265 landscapes offer abundant and accessible food resources for both nesting and foraging and also

266 provide suitable cover and/or protection from predators or harsh weather (Benton et al. 2003;

267 Lima and Dill 1990; Vickery and Arlettaz 2012).

Interestingly, a common feature that describes Woodlarks occurrence in most studies is the

presence of bare soil. The presence of few patches of bare soil have been shown to increase the attractiveness of potential breeding sites in vineyards (Arlettaz et al. 2012). Ground foraging insectivorous birds, like the Woodlark, forage in bare soil due to the high invertebrate prey accessibility, where they can detect and pick up prey items easily (Schaub et al. 2010). Rather than occurrence of bare soil patches, in our study, the arrangement -which has not been evaluated previously- was a predictor of Woodlark territories. A high degree of dispersed bare soil patches indicates the importance of bare soil scattered between grassland and cropland.

276 Thus, the arrangement of bare soil contributes to the heterogeneity of the landscape and complements the resources found in contrasting habitats (i.e., grasslands) (Dolman 2012; Pino et al. 2000). probability of Woodlark territories was higher away from dirt roads. This indicates possible 281 avoidance of human disturbance (Mackowicz 1970; Rösch et al. 2021). However, Woodlarks

282 were seen dust bathing in the sand of dirt roads during the study period. Some farmland species 
283 might tolerate low road traffic and human presence levels if there is optimal habitat for them 284 (Tarjuelo et al. 2020), which might be also the case for Woodlarks. Dirt roads could provide 285 access to food resources on the bare soil or in the short and sparse vegetation found between the 286 track lanes (Harrison and Forster 1959; Schaub et al. 2010). In vineyards, Woodlarks prefer vine287 rows with a vegetation cover as these provide high abundance of invertebrate prey (Bosco et al. 288 2019; Rösch et al. 2021). Therefore, it might be a trade-off between accessing a certain resource 289 (in this case prey) and the perceived risk posed by humans (Mallord et al. 2007b).

In addition, the degree of fragmentation was also relevant for the occurrence of Woodlarks territories. Territories were established in areas with lower patch density suggesting that large and few habitat patches (i.e., low fragmentation) were more attractive than small and numerous patches in the local landscapes. Similarly, Woodlarks avoided fragmented areas in vineyards when the amount of habitat was less than $20 \%$ (Bosco et al. 2021). However, at the broad scale

$295\left(1 \mathrm{~km}^{2}\right)$ Woodlarks were more abundant in fragmented steppe habitats (Campedelli et al. 2015).

296 This highlights the interplay between the composition and configuration of habitat patches and

297 the difficulty of generalising conservation strategies derived from analysis at different spatial 298 scales.

The scale of analysis might also explain why some previously identified characteristics did not play a role in our study. Here, we focused on the local landscape. Those studies, where the

301 height of grass/herbs was relevant, were at the microhabitat scale (immediate surroundings 302 around the nest) (Buehler et al. 2017; Harrison and Forster 1959; Mallord et al. 2007).

303 Alternatively, Woodlarks' habitat association might change within the breeding season

304 (Brambilla and Rubolini 2009). In our study, we focused on the first clutch, so assessment on 305 whether habitat associations change and which factors may become an important predictor late in 
306 the breeding season requires further study. Other studies have found that Woodlarks were

307 associated with the presence and proximity to woodland in steppe landscapes (Campedelli et al.

308 2015; Schaefer and Vogel 2000) which was also not the case in our study. Although the

309 proportion of woodland was a habitat element in our study area, it was not relevant by itself but

310 contributed to the overall heterogeneity of the landscape. Thus, habitat associations vary across

311 the Woodlark's geographical range as these are context-dependent (Whittingham et al. 2007), but

312 landscape heterogeneity was the ubiquitous attribute at multiple spatial scales and across its

313 range.

314 Interestingly, we did not detect any significant land-use changes from 2007 to 2016 . The

315 proportion of land-use types considered was similar during this period, which could be attributed

316 to the 'stabilisation of intensification' that happened in most regions in Europe from 2001 to

3172011 (van der Sluis et al. 2016). However, it is important to note that we evaluated these changes

318 at the regional level and other forms of intensification like increasing the use of artificial

319 pesticides might play a greater role at the local level (Kristensen et al. 2016) and potentially

320 affect Woodlark populations (Kristensen et al. 2016).

In conclusion, landscape heterogeneity was a key habitat characteristic for Woodlarks as

322 was previously identified across its range. In addition, the configuration of habitat elements

323 should be considered when assessing habitat associations. Even though there was no evidence of

324 changes in land use up to 2016 , further monitoring is recommended to mitigate potential effects

325 it might have on Woodlarks' habitats. Although some conservation recommendations can be

326 derived from other regions, for example, maintaining or enhancing landscape heterogeneity (e.g.,

327 Bosco et al. 2019; Fartmann et al. 2018; Sirami et al. 2011), others should change with local

328 conditions because important habitat characteristics vary across its range. In Upper Austria, 
329 management and conservation efforts should focus on maintaining or enhancing a mixed-habitat

330 landscape of grassland, cropland, forest, and bare soil. These elements should be aggregated

331 except for bare soil which should be dispersed. Finally, new dirt road development should be

332 limited or located away from areas known to have Woodlarks territories. Together, these

333 measures will benefit Woodlarks and inform future conservation management in Upper Austria.

\section{Acknowledgements}

335 We would like to thank H. Uhl, A. Schmalzer, H. Rubenser and H. Kurz from BirdLife Austria

336 for their support during the field mapping.

\section{References}

338 Aitchison J (1982) The statistical analysis of compositional data. J R Stat Soc 44:139-177 https://doi.org/10.1111/j.2517-6161.1982.tb01195.x

340 Arlettaz R, Maurer ML, Mosimann-Kampe P, Nusslé S, Abadi F, Braunisch V, Schaub M (2012)

341 New vineyard cultivation practices create patchy ground vegetation, favouring

342 Woodlarks. J Ornithol 153:229-238 https://doi.org/10.1007/s10336-011-0737-7

343 Barton K (2020) MuMIn: Multi-Model Inference. R package version 1.43.17. https://CRAN.R$344 \quad$ project.org/package=MuMIn.

345 Benton TG, Vickery JA, Wilson JD (2003) Farmland biodiversity: is habitat heterogeneity the key? Trends Ecol Evol 18:182-188 https://doi.org/10.1016/S0169-5347(03)00011-9

BMLFUW (2017) Grüner Bericht 2017 - Bericht über die Situation der österreichschen Landund Forstwitschaft. Federal Ministry for Agriculture, Forestry, Environment and Water Management, Vienna, Austria Available at gruenerbericht.at/cm4/jdownload/download/2-gr-bericht-terreich/1773-gb2017 
351 Bosco L, Arlettaz R, Jacot A (2019) Ground greening in vineyards promotes the Woodlark

$352 \quad$ Lullula arborea and their invertebrate prey. J Ornithol 160:799-811

353 https://doi.org/10.1007/s10336-019-01666-7

354 Bosco L, Cushman SA, Wan HY, Zeller KA, Arlettaz R, Jacot A (2021) Fragmentation effects 355 on woodlark habitat selection depend on habitat amount and spatial scale. Anim Conserv 24:84-94 https://doi.org/10.1111/acv.12604

357

358

359

360

361

362

363

364

365

366

367

368

369

370

371

372

373

Boves TJ, Buehler DA, Sheehan J, Wood PB, Rodewald AD, Larkin JL, Keyser PD, Newell FL, Evans A, George GA, Wigley TB (2013) Spatial variation in breeding habitat selection by Cerulean Warblers (Setophaga cerulea) throughout the Appalachian mountains. Auk 130:46-59 https://doi.org/10.1525/auk.2012.12104

Brambilla M, Falco R, Negri I (2012) A spatially explicit assessment of within-season changes in environmental suitability for farmland birds along an altitudinal gradient. Anim Conserv 15:638-647 https://doi.org/10.1111/j.1469-1795.2012.00561.x

Brambilla M, Rubolini D (2009) Intra-seasonal changes in distribution and habitat associations of a multi-brooded bird species: implications for conservation planning. Anim Conserv 12:71-77 https://doi.org/10.1111/j.1469-1795.2008.00226.x

Breiman L (2001) Random Forests. Mach Learn 45:5-32

Buehler R, Bosco L, Arlettaz R, Jacot A (2017) Nest site preferences of the Woodlark (Lullula arborea) and its association with artificial nest predation. Acta Oecol 78:41-46 https://doi.org/10.1016/j.actao.2016.12.004

Campedelli T, Londi G, Gioia GL, Frassanito AG, Florenzano GT (2015) Steppes vs. crops: is cohabitation for biodiversity possible? Lessons from a national park in southern Italy. Agric, Ecosyst Environ 213:32-38 https://doi.org/10.1016/j.agee.2015.07.012 
374 Chamberlain DE, Fuller RJ, Bunce RGH, Duckworth JC, Shrubb M (2000) Changes in the

375 abundance of farmland birds in relation to the timing of agricultural intensification in

376 England and Wales. J Appl Ecol 37:771-788 https://doi.org/10.1046/j.13652664.2000.00548.x

378

379

380

381

382

383

384

385

386

387

388

389

390

391

392

393

394

Dolman PM (2012) Mechanisms and processes underlying landscape structure effects on bird populations. In: Fuller RJ (ed) Birds and Habitat: Relationships in Changing Landscapes. Cambridge University Press, Cambridge, UK, pp 93-124

Donald PF, Green RE, Heath MF (2001) Agricultural intensification and the collapse of Europe's farmland bird populations. Proc R Soc Lond B 268:26825-26829 https://doi.org/10.1098/rspb.2000.1325

Donald PF, Sanderson FJ, Burfield IJ, van Bommel FPJ (2006) Further evidence of continentwide impacts of agricultural intensification on European farmland birds, 1990-2000. Agric, Ecosyst Environ 116:189-196 https://doi.org/10.1016/j.agee.2006.02.007

Dunning JB, Danielson BJ, Pulliam HR (1992) Ecological processes that affect populations in complex landscapes. Oikos 65:169-175

Dvorak M, Landmann A, Teufelbauer N, Wichmann G, Berg H-M, Probst R (2017) Erhaltungszustand und Gefährdungssituation der Brutvögel Österreichs: Rote Liste (5. Fassung) und Liste für den Vogelschutz prioritärer Arten (1. Fassung). Egretta 55:6-42

Dvorak M, Pollheimer M, T. Z-K, Föger M, Pollheimer J, Donnerbaum K (2009) Verbreitung und Bestand der Heidelerche (Lullula arborea) am Westufer des Neusiedler Sees im Jahr 2006. Vogelkundliche Nachrichten aus Ostösterreich 20 1-4/2009:1-6 
395 EBCC (2021) Pan-European Common Bird Monitoring Scheme. European Bird Census Council.

396 https://pecbms.info/trends-and-indicators/species-trends/species/lullula-arborea/.

$397 \quad$ Accessed 20 April 2021

398 ESRI (2017) ArcGIS Desktop, Version 10.5.1 edn. Environmental Systems Research Institute, 399 Redlands, California, USA

400 Fahrig L (2013) Rethinking patch size and isolation effects: the habitat amount hypothesis. J Biogeogr 40:1649-1663 https://doi.org/10.1111/jbi.12130

402

403

404

405

406

407

408

409

410

411

412

414

415

416

417

Fartmann T, Kämpfer S, Brüggeshemke J, Juchem M, Klauer F, Weking S, Löffler F (2018) Landscape-scale effects of Christmas-tree plantations in an intensively used lowmountain landscape - Applying breeding bird assemblages as indicators. Ecol Indicators 94:409-419 https://doi.org/10.1016/j.ecolind.2018.07.006

Fuller RA (2002) Spatial differences in habitat selection and occupancy by woodland bird species in Europe: a negledted aspect of bird-habitat relationships. In: Chamberlain DE, Wilson A (eds) Avian Landscape Ecology. IALE (UK), Thetford, pp 101-111

Fuller RJ, Rothery P (2013) Temporal consistency in fine-scale habitat relationships of woodland birds during a period of habitat deterioration. For Ecol Manage 289:164-174 https://doi.org/10.1016/j.foreco.2012.09.035

Gil-Tena A, De Cáceres M, Ernoult A, Butet A, Brotons L, Burel F (2015) Agricultural landscape composition as a driver of farmland bird diversity in Brittany (NW France). Agric, Ecosyst Environ 205:79-89 https://doi.org/10.1016/j.agee.2015.03.013

Gregory RD, Skorpilova J, Vorisek P, Butler S (2019) An analysis of trends, uncertainty and species selection shows contrasting trends of widespread forest and farmland birds in Europe. Ecol Indicators 103:676-687 https://doi.org/10.1016/j.ecolind.2019.04.064 
418 Harrison CJO, Forster J (1959) Woodlark territories. Bird Study 6:60-68

419 https://doi.org/10.1080/00063655909475933

420 Havlíček J, Riegert J, Bandhauerová J, Fuchs R, Šálek M (2021) Species-specific breeding

421 habitat association of declining farmland birds within urban environments: conservation

422 implications. Urban Ecosyst https://doi.org/10.1007/s11252-021-01111-9

423 Højsgaard S, Halekoh U, J. Y (2006) The R Package geepack for Generalized Estimating $424 \quad$ Equations. J Stat Softw 15:1-11

425 Holloway S (1996) The Historical Atlas of Breeding Birds in Britain and Ireland: 1875-1900.

$426 \quad$ Poyser, London, UK

427 Hothorn T, Buehlmann P, Dudoit S, Molinaro A, Van Der Laan M (2006) Survival ensembles.

$428 \quad$ Biostatistics 7:355-373

429 Hothorn T, Zeileis A (2015) partykit: A modular toolkit for recursive partytioning in R. J Mach

$430 \quad$ Learn Res 16:3905-3909

431 Jerrentrup JS, Dauber J, Strohbach MW, Mecke S, Mitschke A, Ludwig J, Klimek S (2017)

432 Impact of recent changes in agricultural land use on farmland bird trends. Agric, Ecosyst

$433 \quad$ Environ 239:334-341 https://doi.org/10.1016/j.agee.2017.01.041

434 Kirchner M, Schönhart M, Schmid E (2016) Spatial impacts of the CAP post-2013 and climate 435 change scenarios on agricultural intensification and environment in Austria. Ecol Econ $436 \quad$ 123:35-56 https://doi.org/https://doi.org/10.1016/j.ecolecon.2015.12.009

437 Koleček J, Reif J, Weidinger K (2015) The abundance of a farmland specialist bird, the skylark, 438 in three European regions with contrasting agricultural management. Agric, Ecosyst 439 Environ 212:30-37 https://doi.org/https://doi.org/10.1016/j.agee.2015.06.018 
440 Kristensen SBP, Busck AG, van der Sluis T, Gaube V (2016) Patterns and drivers of farm-level

$441 \quad$ land use change in selected European rural landscapes. Land Use Policy 57:786-799

$442 \quad$ https://doi.org/https://doi.org/10.1016/j.landusepol.2015.07.014

443 Lima S, Dill L (1990) Behavioral decisions made under the risk of predation: a review and

444 prospectus. Can J Zool 68:619-640 https://doi.org/10.1139/z90-092

445 Mackowicz R (1970) Biology of the woodlark Lullula arborea (Linnaeus, 1758) (Aves) in the

446 Rzepin forest (western Poland). Acta Zool Cracov 15:61-160

447 Mallord JW, Dolman PM, Brown A, Sutherland WJ (2007) Nest-site characteristics of

448 Woodlarks Lullula arborea breeding on heathlands in southern England: are there

449

consequences for nest survival and productivity? Bird Study 54:307-314

450

https://doi.org/10.1080/00063650709461490

451 Mallord JW, Dolman PM, Brown AF, Sutherland WJ (2007b) Linking recreational disturbance to population size in a ground-nesting passerine. J Appl Ecol 44:185-195 https://doi.org/10.1111/j.1365-2664.2006.01242.x

McGarigal K, Cushman SA, Ene E (2012) FRAGSTATS v4: spatial pattern analysis program for categorical and continuous maps. Computer software program produced by the authors at the University of Massachusetts, Amherst. Available at http://www.umass.edu/landeco/research/fragstats/fragstats.html.

Naimi B (2015) usdm: Uncertainty analysis for species distribution models. R package version 4.0.4, https://CRAN.R-project.org/package=usdm

Newson SE, Ockendon N, Joys A, Noble DG, Baille SR (2009) Comparison of habitat-specific trends in the abundance of breeding birds in the UK. Bird Study 56:233-243 
462 Pino J, Rodà F, Ribas J, Pons X (2000) Landscape structure and bird species richness:

463 implications for conservation in rural areas between natural parks. Landsc Urban Plan $464 \quad$ 49:35-48 https://doi.org/10.1016/S0169-2046(00)00053-0

465 Piotr T, Tibor H, András B, Paweł S, Marcin T, Irina H, Artur G, Martin K, Martin H, Leszek J, 466 Krzysztof K, Magdalena L, Grzegorz O, Marek P, Piotr S, Tim HS, Stanisław T, Andrzej 467 468 W, Michał Ż (2011) Conservation of farmland birds faces different challenges in western

R Core Team (2020) R: a language and environment for statistical computing http://www.Rproject.org, R version 4.0.3 edn., R Foundation for Statistical Computing, Vienna, Austria

Reif J, Hanzelka J (2016) Grassland winners and arable land losers: The effects of posttotalitarian land use changes on long-term population trends of farmland birds. Agric, Ecosyst Environ 232:208-217 https://doi.org/https://doi.org/10.1016/j.agee.2016.08.007

Rösch V, Aloisio P, Entling MH (2021) Prey, management and landscape requirements of an endangered population of the Woodlark Lullula arborea in Southwest Germany. J Ornithol https://doi.org/10.1007/s10336-021-01862-4

Schaefer T, Vogel B (2000) Why do Woodlarks need field-forest ecotones?-An analysis of possible factors [Wodurch ist die Waldrandlage von Revieren der Heidelerche (Lullula arborea) bedingt — Eine Analyse möglicher Faktoren]. J Ornithol 141:335-344 https://doi.org/10.1007/BF02462243

Schaub M, Martinez N, Tagmann-Ioset A, Weisshaupt N, Maurer ML, Reichlin TS, Abadi F, Zbinden N, Jenni L, Arlettaz R (2010) Patches of bare ground as a staple commodity for 
485

486

487 488 489

declining ground-foraging insectivorous farmland birds. PLoS ONE 5:e13115. https://doi.org/10.1371/journal.pone.0013115

Sharrock JTR (1976) The Atlas of Breeding Birds in Britain and Ireland. Poyser, London, UK

Sirami C, Brotons L, Martin J-L (2011) Woodlarks and landscape heterogeneity created by land abandonment. Bird Study 58:99-106 https://doi.org/10.1080/00063657.2010.532861

Sitters HP, Fuller RJ, Hoblyn RA, Wright MT, Cowie N, Bowden CGR (1996) The Woodlark Lullula arborea in Britain: population trends, distribution and habitat occupancy. Bird Study 43:172-187 https://doi.org/10.1080/00063659609461010

Stanton RL, Morrissey CA, Clark RG (2018) Analysis of trends and agricultural drivers of farmland bird declines in North America: A review. Agric, Ecosyst Environ 254:244-254 https://doi.org/10.1016/j.agee.2017.11.028

Straka U (2008) Ein Brutvorkommen der Heidelerche, Lullula arborea (Linnaeus 1758), in den Donauauen im Tullnerfeld (NÖ). Egretta 49:56-57

Strobl C, Boulesteix A-L, Kneib T, Augustin T, Zeileis A (2008) Conditional variable importance for random forests. BMC Bioinform 9:307 https://doi.org/10.1186/14712105-9-307

Südbeck P, Andretzke H, Fischer S, Gedeon K, Schikore T, Schröder K, Sudfeld C (2005) Methodenstandards zur Erfassung der Brutvögel Deutschlands. Radolfzell Max-PlanckInst für Ornithologie, Vogelwarte Radolfzell

Takacs V, Mizera T, Kujawa D, O'Brien CD (2020) Can't see the Woodlark for the trees? Commercial forests as a habitat for a bird of conservation concern. For Ecol Manage 476:118409 https://doi.org/10.1016/j.foreco.2020.118409 
507 Tarjuelo R, Benítez-López A, Casas F, Martín CA, García JT, Viñuela J, Mougeot F (2020)

508 Living in seasonally dynamic farmland: The role of natural and semi-natural habitats in

509 the movements and habitat selection of a declining bird. Biol Conserv 251:108794

$510 \quad$ https://doi.org/10.1016/j.biocon.2020.108794

511 Uhl H, Wichmann G (2018) Artenschutz- und Monitoringprojekte zugunsten gefährdeter

512 Kulturlandschaftsvögel in Oberösterreich, 2015-2017 BirdLife Austria, Vienna, Austria

513 Uhl H (2009) Wiesenvögel in Oberösterreich 2008. Ergebnisse der landesweiten

514 Bestandserhebungen 1994 bis 2008 und Naturschutzbezüge. BirdLife Austria, Vienna,

$515 \quad$ Austria

516 Uhl H, Wichmann G (2013) Wiesen- und Kulturlandschaftsvögel in Oberösterreich 2011-2013.

$517 \quad$ BirdLife Austria, Vienna, Austria

518 van den Boogaart KG, Tolosana-Delgado R (2013) Analyzing Compositional Data with R.

$519 \quad$ Springer, Berlin, Germany. doi:10.1007/978-3-642-36809-7

520 van den Boogaart KG, Tolosana-Delgado R, Bren M (2021) compositions: Compositional Data

521 Analysis. R package version 2.0-1.:https://CRAN.R-project.org/package=compositions

522 van der Sluis T, Pedroli B, Kristensen SBP, Lavinia Cosor G, Pavlis E (2016) Changing land use

$523 \quad$ intensity in Europe - Recent processes in selected case studies. Land Use Policy 57:777-

$524 \quad 785$ https://doi.org/10.1016/j.landusepol.2014.12.005

525 van Vliet J, de Groot HLF, Rietveld P, Verburg PH (2015) Manifestations and underlying drivers

526 of agricultural land use change in Europe. Landsc Urban Plan 133:24-36

527 https://doi.org/https://doi.org/10.1016/j.landurbplan.2014.09.001

528 Vickery JA, Arlettaz R (2012) The importance of habitat heterogeneity at multiple scales for

529 birds in European agricultural landscapes. In: Fuller RJ (ed) Birds and Habitat: 

177-204

532 Wesołowski T, Fuller RJ (2012) Spatial variation and temporal shifts in habitat use by birds at

533

534

535

536

537

538

539

540

541

542

543

544

545

546

547

548

549

the European scale. In: Fuller RJ (ed) Birds and Habitat: Relationships in Changing Landscapes. Cambridge University Press, Cambridge, UK, pp 63-92

Whittingham MJ, Krebs JR, Swetnam RD, Vickery JA, Wilson JD, Freckleton RP (2007) Should conservation strategies consider spatial generality? Farmland birds show regional not national patterns of habitat association. Ecol Lett 10:25-35 https://doi.org/10.1111/j.14610248.2006.00992.x

Whittingham MJ, Swetnam RD, Wilson JD, Chamberlain DE, Freckleton RP (2005) Habitat selection by yellowhammers Emberiza citrinella on lowland farmland at two spatial scales: implications for conservation management. J Appl Ecol 42:270-280 https://doi.org/10.1111/j.1365-2664.2005.01007.x

Wotton SR, Gillings S (2000) The status of breeding woodlarks Lullula arborea in Britain in 1997. Bird Study 47:212-224

Wright LJ, Hoblyn RA, Sutherland WJ, Dolman PM (2007) Reproductive success of Woodlarks Lullula arborea in traditional and recently colonized habitats. Bird Study 54:315-323 https://doi.org/10.1080/00063650709461491

Zuur AF, Ieno EN, Walker NJ, Saveliev AA, Smith GM (2009) Mixed Effects Models and Extensions in Ecology with R. Springer, New York 


\section{Table 1 (on next page)}

Result of the Generalized Estimating Equation model with absence and presence as response variable and non-collinear predictors identified by the conditional random forest algorithm as explanatory variables.

The table shows the estimate, standard error (SE), Wald value and $p$-value (P), significant results are in bold. 


\begin{tabular}{lllll}
\hline & Estimate & SE & Wald & P \\
\hline (Intercept) & -0.416 & 0.061 & 46.9 & $<\mathbf{0 . 0 0 1}$ \\
Landscape heterogeneity & 1.988 & 0.287 & 47.9 & $<\mathbf{0 . 0 0 1}$ \\
Distance from dirt roads & 0.870 & 0.136 & 41.6 & $<\mathbf{0 . 0 0 1}$ \\
Landscape shape index of & 0.438 & 0.076 & 33.5 & $<\mathbf{0 . 0 0 1}$ \\
bare soil & & & & \\
Patch density & -0.354 & 0.043 & 69.2 & $<\mathbf{0 . 0 0 1}$ \\
\hline
\end{tabular}

2 
Figure 1

Location of the field sites in Neumarkt and Nature Park in Upper Austria, Austria.

Occupied Woodlark territories are depicted with circles $(n=18)$ and non-territories with triangles ( $n=16$ ). Land cover based on the 2018 CORINE Land cover map available at the Copernicus Land Monitoring Service (https://land.copernicus.eu/).

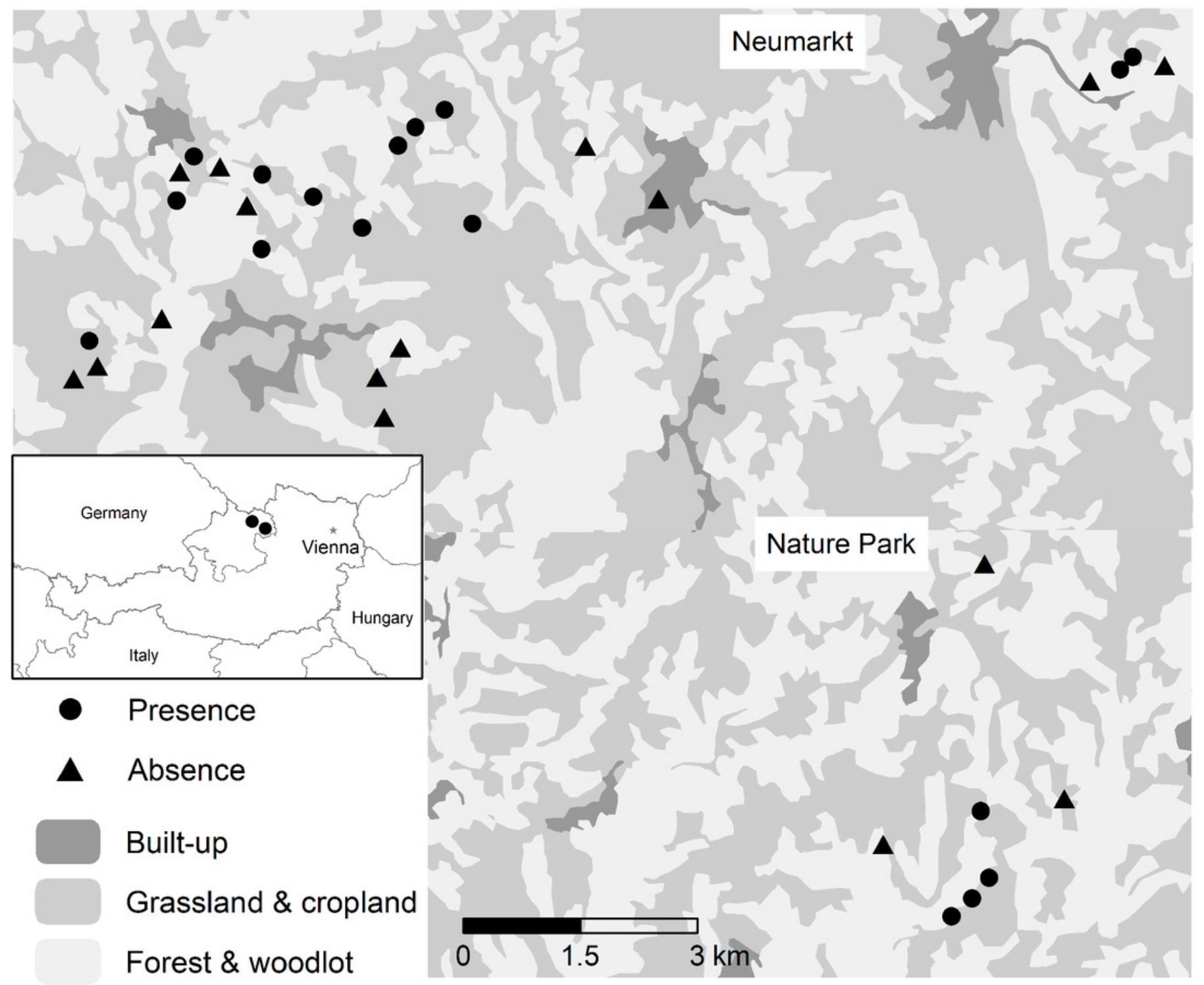




\section{Figure 2}

Conditional variable importance of the top nine variables based on the conditional random forest analysis.

Landscape heterogeneity (SIDI), length of dirt road (len_dirt_rd), proportion of dirt roads (PLAND_dirt_rd), patch density of the landscape (PD), landscape shape index of bare soil (LSI_soil_A), patch density of grassland (PD_grassland), proportion of bare soil (PLAND_soil_A), distance from dirt roads (dis_dirt_rd), and contagion index (CONTAG).

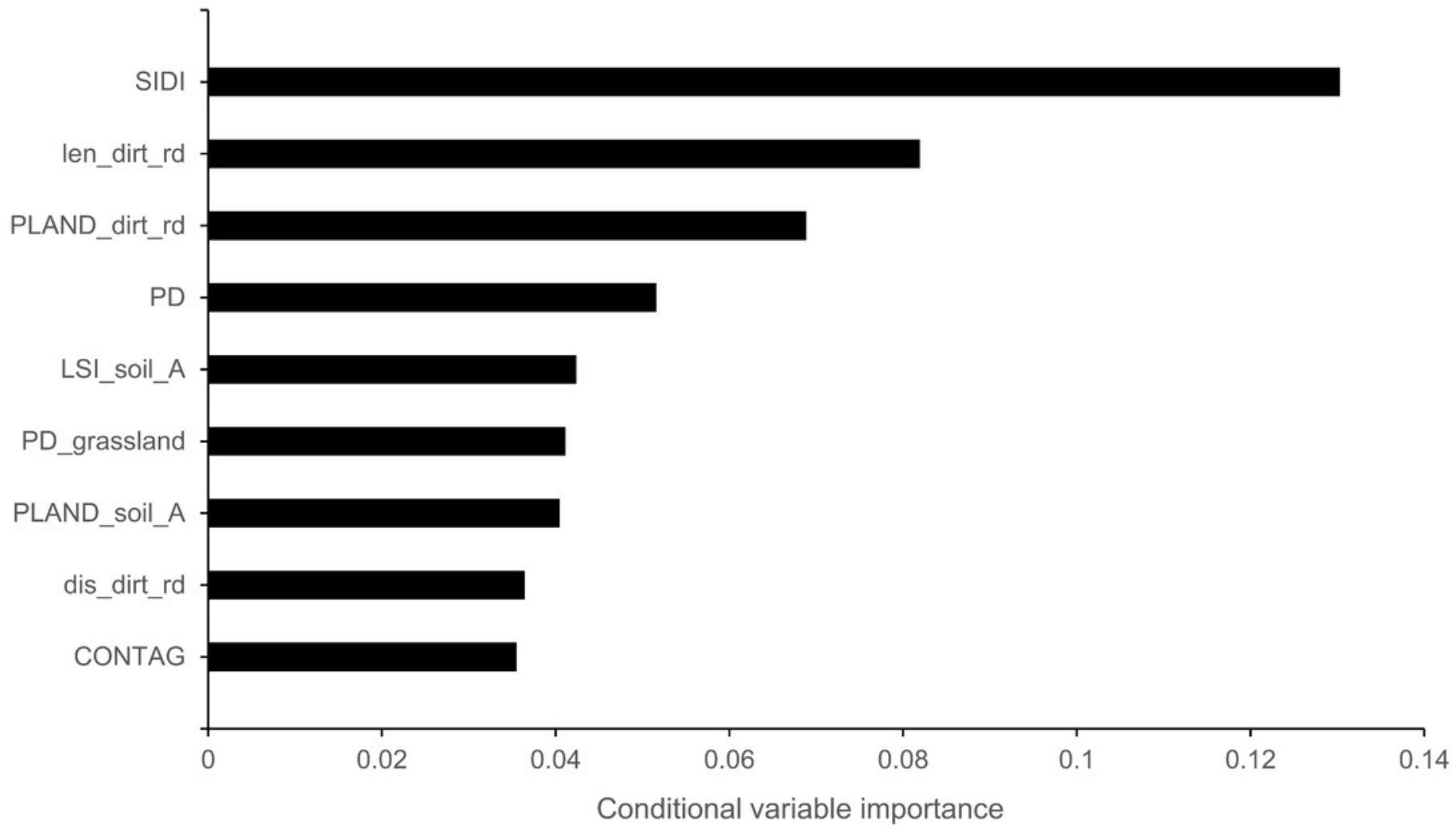




\section{Figure 3}

Fitted values (line) and 95\% confidence intervals (grey) obtained by the Generalized Estimating Equation model depicting the probability of the occurrence of Woodlark territories and significant predictors

(A) landscape heterogeneity represented by the Simpson diversity index, (B) distance from dirt roads, (C) landscape shape index of bare soil, and (D) patch density. 

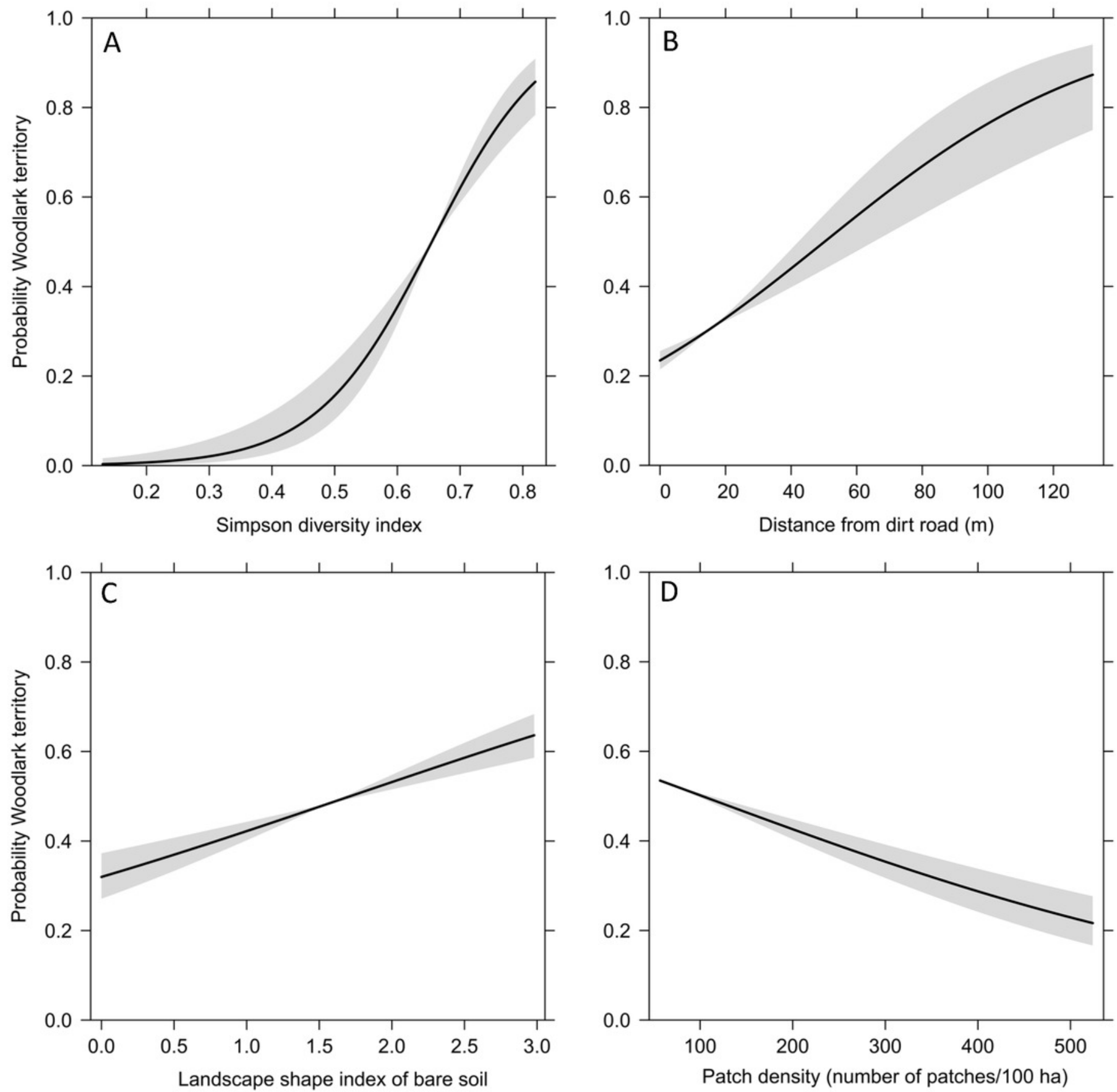


\section{Figure 4}

Bar chart representing the parameters of a linear model with compositional response and year as main effect.

Grey tones depict the associated land-use type: grassland (black), cropland (mid-grey), woodland (light grey), and protected (white).

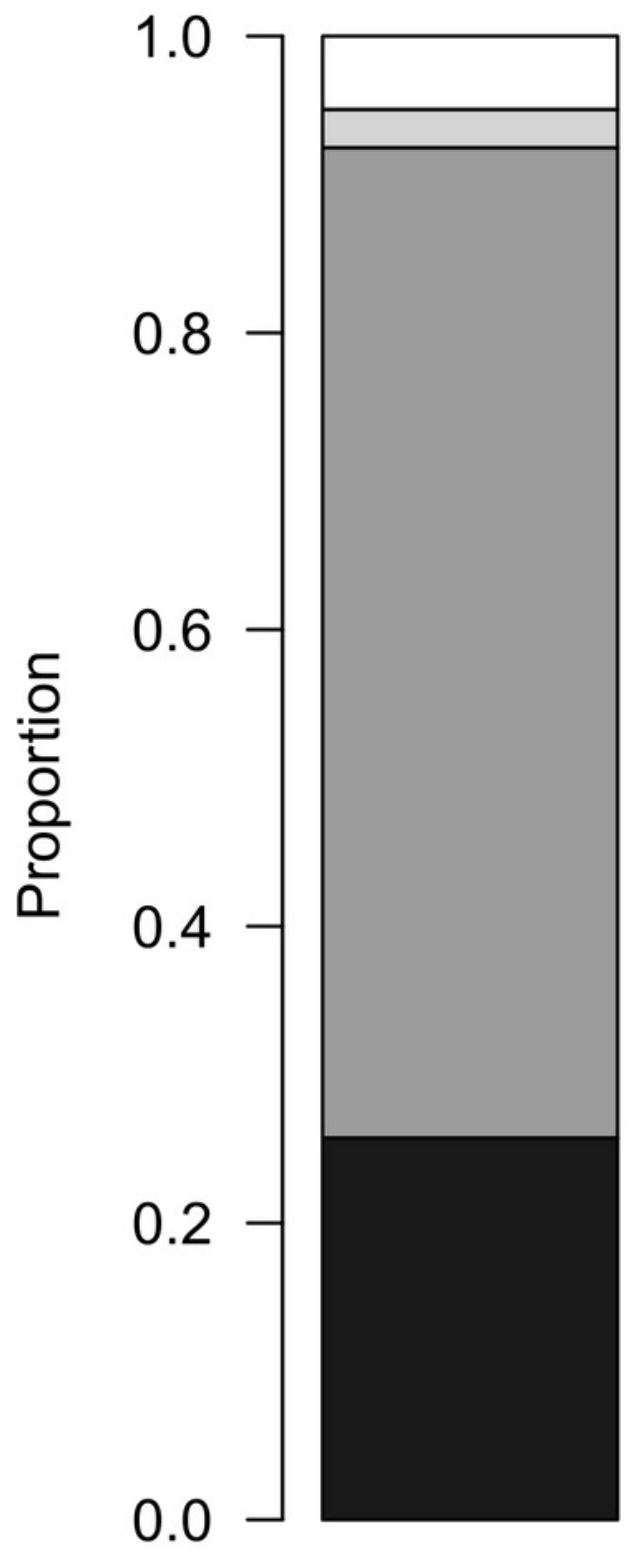

(Intercept)

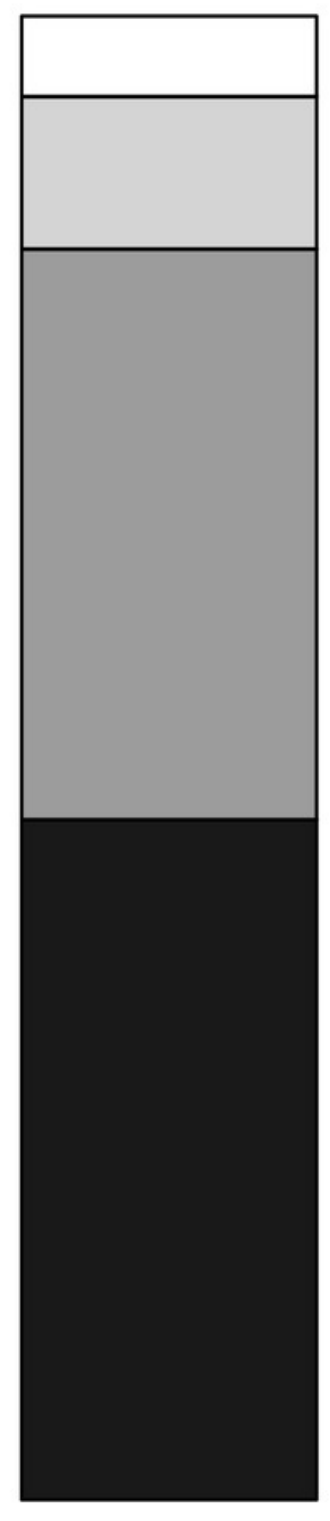

2012

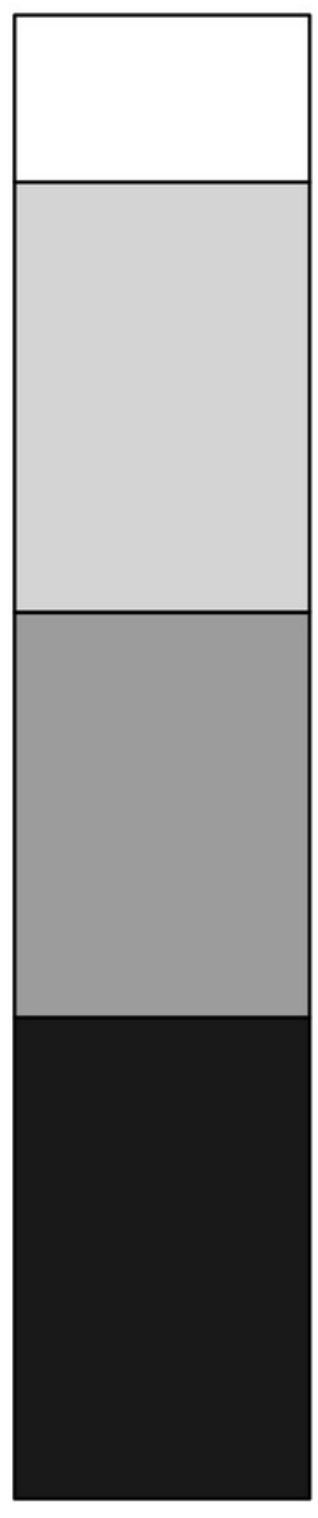

2016 